\title{
Biological and distributional overview of the genus Eledonoprius (Coleoptera: Tenebrionidae): Rare fungus-feeding beetles of European old-growth forests
}

\author{
Giuseppe M. CARPanetO ${ }^{1}$, Stefano Chiari ${ }^{1}$, Paolo A. AUdisiO ${ }^{2}$, Piero LeO $^{3}$, Andrea Liberto ${ }^{4}$, \\ NiCKLAS JANSSON ${ }^{5}$ and AgNESE ZAULI ${ }^{1}$ \\ ${ }^{1}$ Dipartimento di Biologia Ambientale, Università degli Studi Roma Tre, Viale G. Marconi 446, 00146 Roma, Italy; \\ e-mails: carpanet@uniroma3.it; schiari@uniroma3.it; agnese.zauli@libero.it \\ ${ }^{2}$ Dipartimento di Biologia e Biotecnologie “Charles Darwin”, Università degli Studi La Sapienza, Viale Borelli 50, 00185 Roma, \\ Italy; e-mail: paolo.audisio@uniroma1.it \\ ${ }^{3}$ Via P. Tola 21, 09128 Cagliari, Italy; e-mail: piero.leo@tiscali.it \\ ${ }^{4}$ Via C. Pilotto 85/F 15, 00139 Roma, Italy; e-mail: andrea.liberto@ansa.it \\ ${ }^{5}$ Department of Physics, Chemistry and Biology, Linköping University, 58183 Linköping, Sweden; e-mail: nicja@ifm.liu.se
}

Key words. Tenebrionidae, Eledonoprius, saproxylic fauna, mycophagy, bracket fungi, forest ecosystems, old trees, cork oaks

\begin{abstract}
All the information on the genus Eledonoprius was gathered to provide an up to-date overview of the geographical distribution and ecology of its species, and to assess their association with old-growth forests. Based on recent samples collected in deciduous forests and woodlands of Italy, the authors outline the habitats of these rare species and give an account of their trophic relations with bracket fungi. E. armatus is recorded in Central Italy and Sardinia for the first time; E. serrifrons is new to Basilicata (Southern Italy) and Syria.
\end{abstract}

\section{INTRODUCTION}

The genus Eledonoprius Reitter, 1911, includes only two rare and poorly known species of darkling beetles, both occurring in the western Palaearctic Region: Eledonoprius armatus (Panzer, 1799) and E. serrifrons Reitter, 1890. According to the few records in the literature these small beetles $(2.7-3.8 \mathrm{~mm})$ are mainly associated with bracket fungi (Polyporaceae) that grow on the trunks of old broadleaf trees. These ecological features and the scattered populations of the species indicate that these beetles are relict representatives of a fauna associated with oldgrowth deciduous forests (Español, 1985; Stebnicka, 1991; Kompantseva \& Tschigel, 2000; Müller et al., 2005; Castro Tovar et al., 2008). Recently, we found these beetles in other types of deciduous forest in geographic areas where they were not previously recorded. The aim of this paper is to gather all the available information on the genus, add new data and redefine the geographic distribution and ecology of the species.

\section{MATERIAL AND METHODS}

The specimens of Eledonoprius armatus from central Italy were found during an intensive collection of saproxylic beetles, carried out from 2008 to 2011 in the Latium Region, which formed part of a regional project on the monitoring of the saproxylic fauna. Seven different sites were sampled: Selva del Lamone, Monte Venere, Allumiere, Oriolo Romano, Monterano, Pomezia and Bosco Polverino. Types of forest sampled included old stands of evergreen trees, in particular cork oak (Quercus suber) (Pomezia and Bosco Polverino) and deciduous forests, such as beech (Fagus sylvatica) (Monte Venere, Allumiere and Oriolo Romano), turkey oak (Quercus cerris) and mixed broadleaf woodlands (Selva del Lamone and Monterano). Fieldwork consisted of traditional sieving of deadwood, visual inspection of bark and fungi and setting traps in and on hollow trees. The traditional sieving method consisted of placing wood debris in a sieve, breaking it into small pieces and then exam- ining the sieved debris on a white towel. Two types of trap were used: window traps and pitfall traps. The first type of trap (window) intercepts flying beetles by means of a transparent rigid plastic sheet, placed perpendicular to a plastic container half filled with ethylene glycol and water $(50: 50 \mathrm{v} / \mathrm{v})$, to which a few drops of detergent are added to reduce surface tension. These traps were hung from hollow trees, near to an entrance hole. The second type of trap (pitfall), which was set inside hollow trees to catch insects walking inside the cavity, consists of standard plastic glasses full of the same liquid as used in the first type of trap, with the openings level with the wood mould surface. The number of traps of each type used varied from five to eleven. Both window and pitfall traps were operated from April to August and visited every 2 or 3 weeks. Both types of trap captured specimens of Eledonoprius armatus, but only at three localities, Bosco Polverino (pSCI: IT6004004), Allumiere (pSCI IT6030003) and Monte Venere (pSCI: IT6010023), in cork oak stands at the first locality and old-growth beech forests at the other two. Additional records come from the study of specimens in museums and private collections.

Acronyms of insect collections examined: $\mathrm{AD}=$ Agostino Dodero Collection (MCSN); $\mathrm{AL}=$ Andreo Liberto Collection, Roma, Italy; $\mathrm{CM}=$ Carlo Meloni Collection (MCSN); $\mathrm{GC}=$ Giuseppe Carpaneto Collection (MZURT); HB = Hervé Brustel, Toulouse, France; PL = Piero Leo Collection, Cagliari, Italy; CIBIO = Centro Iberoamericano de la Biodiversidad, Universidad de Alicante; MCSN = Museo di Storia Naturale di Genova (= Natural History Museum of Genoa); MZURT = Museo di Zoologia dell'Università Roma Tre (= Zoological Museum of Roma Tre University).

\section{RESULTS}

\section{Eledonoprius armatus (Panzer, 1799)}

Boletophagus armatus Panzer, 1799

Bolitophagus armatus Panzer, 1799 (misspelling) 


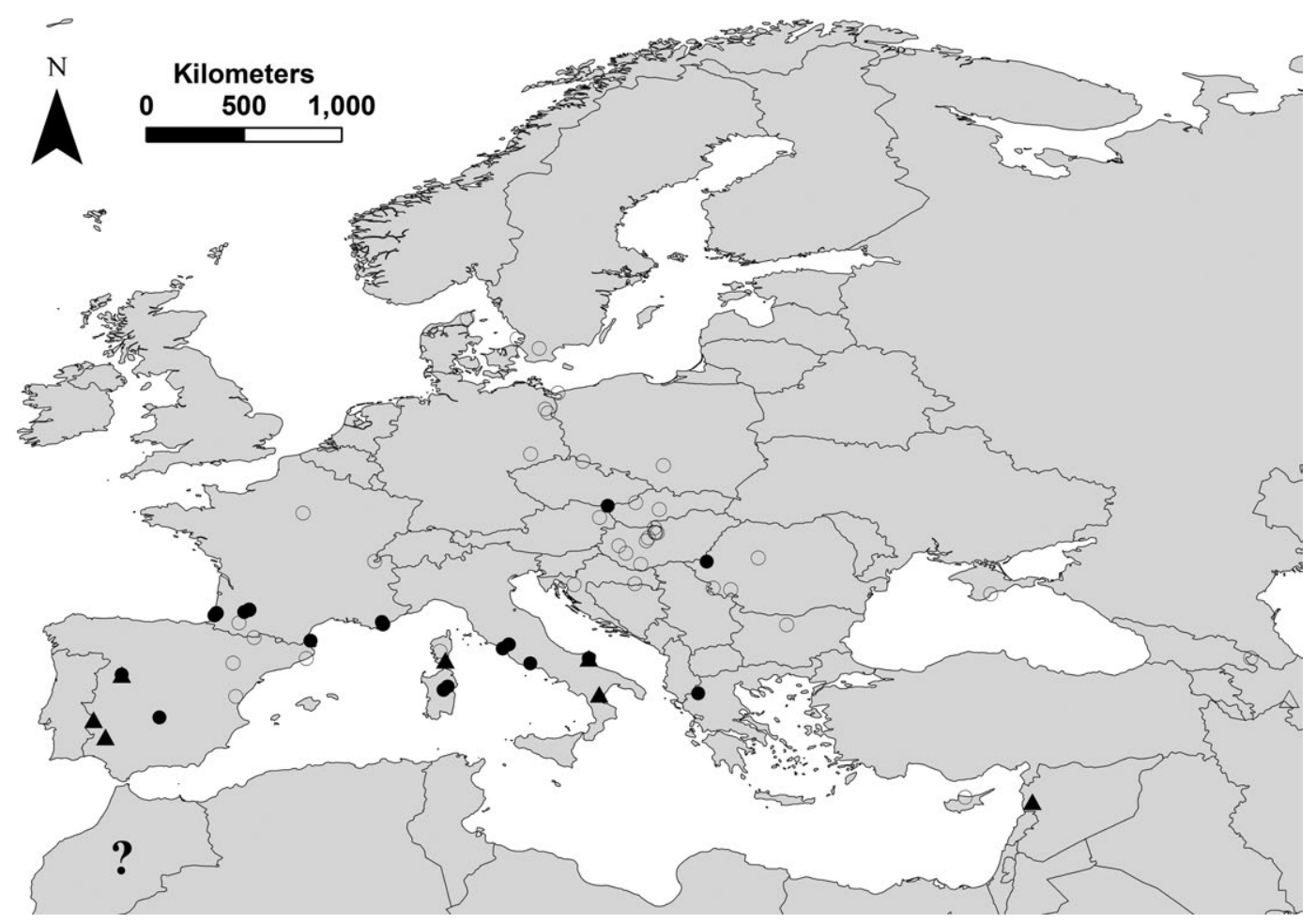

Fig. 1. Map showing the distribution of Eledonoprius armatus (circles) and E. serrifrons (triangles). Open symbols refer to undated or records before 2000 and filled symbols to records since 2000.

\section{New records}

Italy, Lazio Region, Latina Province, Bosco Polverino, $37 \mathrm{~m}$ a.s.1., $\quad 34^{\circ} 84^{\prime} 54^{\prime \prime} \mathrm{E}-45^{\circ} 88^{\prime} 51^{\prime \prime} \mathrm{N}, \quad 30 . i v-21 . v .2009$ (1 $\quad$ ex.), 11.vi.-2.vii.2009 (1 ex.), 23.vii-11.viii.2009 (1 ex.), G. Carpaneto, S. Chiari and A. Zauli leg. (window traps); 30.iv.-21.v.2009 (2 exx.), 21.v-11.vi.2009 (4 exx.), 11.vi.-2.vii. 2009 (1 ex.), 2.-23.vii.2009 (1 ex.), G. Carpaneto, S. Chiari and A. Zauli leg. (pitfall traps) (GC-MZURT). Italy, Lazio Region, Allumiere, $590 \mathrm{~m}$ a.s.1., $11^{\circ} 54^{\prime} 66^{\prime \prime} \mathrm{E}-42^{\circ} 09^{\prime} 19^{\prime \prime} \mathrm{N}$, 7.v.-21.v.2011 (1 ex.) G. Carpaneto and L. Redolfi De Zan leg. (pitfall traps) (GC-MZURT). Italy, Lazio Region, Viterbo Province, Monte Venere, $829 \mathrm{~m}$ a.s.1., $12^{\circ} 10^{\prime} 88^{\prime \prime} \mathrm{E}-42^{\circ} 20^{\prime} 73^{\prime \prime} \mathrm{N}, 3 . v i .-18 . v i .2011$ (2 ex.) G. Carpaneto and L. Redolfi De Zan leg. (window traps); 630 m a.s.1., $12^{\circ} 11^{\prime} 23^{\prime \prime} \mathrm{E}-42^{\circ} 21^{\prime} 06^{\prime \prime} \mathrm{N}, 21 . v .-3 . v i .2011$ (1 ex.) G. Carpaneto and L. Redolfi De Zan leg. (pitfall traps); $630 \mathrm{~m}$ a.s.l., $12^{\circ} 11^{\prime} 23^{\prime \prime} \mathrm{E}-42^{\circ} 21^{\prime} 06^{\prime \prime} \mathrm{N}$, 15.vii.-29.vii.2011 (1 ex.) G. Carpaneto and L. Redolfi De Zan leg. (pitfall traps) (GC-MZURT). Italy, Sardegna region, Nuoro Province, Orune (1 ex. AD-MCSN); Monte Gonare, v.2003, C. Meloni leg. (in hollow trunk of cork oak, Quercus suber) (5 exx. CM-MCSN, 2 exx. PL). Romania, Arad, Grosii Noi Natural Reserve, 26.vi.2005, H. Brustel leg. (1 ex. HB). Spain, Salamanca, Campanarios de Azaba, $900 \mathrm{~m}$ a.s.1., $6^{\circ} 47.551^{\prime} \mathrm{W}-40^{\circ} 29.769^{\prime} \mathrm{N}, 21 . \mathrm{v} .2010(1$ ex.), 7.vi.2011 (1 ex.), E. Micó et al. leg. (window traps) (CIBIO) (E. Micó, pers. com.).

\section{Eledonoprius serrifrons (Reitter, 1890)}

\section{New records}

Italy, Basilicata Region, Potenza Province, Cersòsimo (at confluence between Lappio stream and Sarmento river) $400 \mathrm{~m}$ a.s.1., $40^{\circ} 03^{\prime} 95^{\prime \prime} \mathrm{N}-16^{\circ} 20^{\prime} 63^{\prime \prime} \mathrm{E}, 16 . v i .2003$, A. Liberto leg. (on Populus nigra) (1 ex. PL, 4 exx. AL). Spain, Salamanca, Campanarios de Azaba, $900 \mathrm{~m}$ a.s.1., 647.551'W-40'29.769'N, 21.v.2010 (1 ex.), 27.vi.2010 (2 exx.), 7.vi.2011 (2 exx.), 9.vii.2011 (1 ex.), E. Micó et al. leg. (window traps) (CIBIO) (E. Micó, pers. com.).
Spain, Cáceres, Monfragüe National Park, Las Cansinas, 24.x.2008, H. Brustel leg. (in Inonotus sp., on Fraxinus) (1 ex. HB). Syria, Slunfeh, 1300 m, 2.-6.vi.2000, D. Baiocchi leg. (2 exx. PL, 5 exx. AL).

\section{DISCUSSION}

\section{Geographical distribution}

Eledonoprius armatus has a wide geographic range but is restricted to approximately 50 localities in 21 countries (Fig. 1). Most records date back to the second half of the $19^{\text {th }}$ century (e.g. Danish mainland) or the first half of the $20^{\text {th }}$ century (e.g. Germany, Poland, Azerbaijan, Bulgaria), few records refer to the second half of the $20^{\text {th }}$ century (Sweden, Slovenia, Ukraine, Cyprus). Only the records from France, Spain, Italy, Greece, Romania and southern Moravia refer to the first decade of the $21^{\text {th }}$ century. The presence in Morocco (Escalera, 1914) is doubtful.

Eledonoprius serrifrons was described from the Caucasian region, in particular from Azerbaijan (type locality: "Araxesthal", i.e. the Valley of the Araxes River in Azerbaijan) (Reitter, 1890). The geographical range of this species was recently enlarged by the following records for southern Italy, Puglia Region, Monte Gargano (Schawaller, 2002); Spain, Extremadura Region, Cabeza la Vaca (near Badajoz) (Castro Tovar et al., 2008) and Corsica, Palavese (near Porto-Vecchio) (Soldati et al., 2009). Including the records added in the present paper, the species shows a disjunct distribution range including the Iberian Peninsula, Corsica, southern Italy, the Levant and (Syria) and the Caucasian region (Azerbaijan) (6 localities in 4 countries) (Fig. 1). Almost all the records for this species (except the type locality) are very recent and refer to the first decade of the current century. E. serrifrons appears to be rarer and more localized than E. armatus, even though in a protected area of Spain (Campanarios de Azaba) it seems to be more frequent than the latter. 


\section{Biology}

The first author to report ecological information on the genus Eledonoprius was Iablokov (1939) who recorded a close association between E. armatus and the fungus Inonotus obliquus (quoted as Xanthochrous obiquus) in the Forest of Fontainebleau, France. After a great effort, Iablokov (1939) succeeded in collecting sixty individuals of $E$. armatus over a period of fieldwork that lasted five months, from June to October, during which all the beetles were found during visual surveys of fungi and dead standing trees. Some of the adults were teneral indicating they had developed in the above mentioned bracket fungus.

Additional information provided by subsequent investigations: Kompantseva \& Tschigel (2000) found both adults and larvae in the sporocarps of Inonotus cuticularis on beech logs in southern Crimea. This record is the first to prove that $E$. armatus develops inside the sporocarps of I. cuticularis.

In southern France, Brustel et al. (2004) collected and reared larvae of E. armatus in Inonotus radiatus (on Alnus sp.), Inonotus dryadeus and Spongipellis delectans (on Quercus suber) and Inonotus sp. (on Betula). Other larvae were subsequently found by H. Brustel (pers. com.) in France and Spain in Inonotus fungi on Quercus suber and Fraxinus sp. In Sweden the larvae of this species are recorded living in white rot wood behind the bracket fungi Hypoxylon deustum, Auricularia mesenterica and Inonotus cuticularis (Lundberg \& Ehnström, 2006). Adult specimens are recorded from Fistulina hepatica in France (Brustel et al., 2008) and Fomes fomentarius in Corse (Soldati \& Coache, 2004). In Romania (Arad, Grosii Noi National Park), an adult is recorded from Inonotus growing on the trunk of Fagus sylvatica (H. Brustel, pers. com.). Tamisier (2005) collected this species from Inonotus radiatus in Aquitaine, France. In the old beech Foresta Umbra at Monte Gargano, Italy, three adults of E. armatus were collected from Ganoderma lucidum (Schawaller, 2002). A remarkable finding is that reported by Mateleshko (2005) from Ukraine of this species occurring in decaying lamellate fungi of the genus Pleurotus, which needs to be confirmed as the literature indicates that Inonotus species are the main fungal hosts of E. armatus, with most of the larvae recorded from I. cuticularis.

According to Bernicchia (2005), Inonotus species are whiterot-causing bracket fungi and produce annual basidiocarps that develop on the decaying wood of both living and dead trees. Inonotus cuticularis grows mostly on Quercus ilex, $Q$. suber, Celtis australis, Fagus sylvatica and Acer; I. dryadeus is recorded on Quercus robur, $Q$. petraea and $Q$. cerris (rarely on Abies alba); I. obliquus on Betula (in northern latitudes), Fagus (in central and southern Europe) and rarely on other broadleaf trees; I. radiatus occurs most often on Betula, Alnus, Acer and Fagus, but also Quercus ilex and Q. suber. All these species are widely distributed in central and northern Europe, but are less frequent in the Mediterranean region, which may account for the extreme rarity of Eledonoprius in Italy.

Other data from the literature and unpublished records do not support a link between fungi and these beetles. For instance, the ecology of E. armatus in France is discussed by Ponel (1993), who places this species among the beetles living inside hollow cork oaks (Quercus suber) on the hills of Provence (Massif des Maures), but does not mention any association between the beetle and fungi. Seven specimens were collected by emergence traps set in two cavities in Quercus pyrenaica from July to October 2009 in the Cabañeros National Park (central Spain), where there is no evidence of bracket fungi (E. Micó, pers. com.). The recent records from Sardinia, quoted in the present paper, were from the hollow trunk of a cork oak (Quercus suber) on which there were no sporocarps of bracket fungi. The specimens from Bosco Polverino were collected also from hollow trunks of cork oak on which there were no developing sporocarps of bracket fungi. Only one and four specimens of Eledonoprius armatus, respectively, were collected in the two beech forests surveyed during this research (Allumiere and Monte Venere), despite their richness in old trees and fungi. The three beech trees where this species was found did not bear sporocarps of bracket fungi. Based on our records from both cork oak and beech woodlands, there is no definite correlation between the occurrence of sporocarps of bracket fungi and E. armatus, but all the specimens were found in large and deep basal cavities in old trees. It is possible that at the time of our surveys the fungus was in a nonreproductive stage, which could account for the absence of sporocarps. According to A. Bernicchia (pers. com.), the production of the annual sporocarps (basidiocarp) of Inonotus starts after rain between the end of summer and beginning of autumn and they are then destroyed by bacteria, insects and snow during winter. In spring, some remnants of the fruiting body are still visible and the new basidiocarp may develop on the previous one. The hyphae are inside the wood and present even when there is no basidiocarp present.

The specimens (all adult) collected by traps during our research in Latium were probably caught between May and July, perhaps even later, because the traps that caught the last beetle in the latest period were operational from July 23 to August 11 and we did not record the exact date of capture. In the cork oak stand of Bosco Polverino, where the largest numbers of individuals were collected, only three specimens were caught by window traps. This indicates that during the period from May to July these beetles are active flyers, while the eight specimens found in pitfall traps indicate they walk when in the cavities of trees. Each trap did not catch more than one specimen per sample, except for a pitfall trap placed in a cork oak, where four specimens were caught between May 21 and June 11, 2009. From this tree, we collected $64 \%$ (7 of 11) of the specimens captured by traps during the whole sampling period. E. armatus were only caught in four of the eleven cork oaks sampled using traps at Bosco Polverino. Due to the long working period of our traps (21 days), the dates of captures are not very accurate but individuals of $E$. armatus were caught in every trapping session, which indicates the adults are active over a long period. If we consider all the data available on phenology (including those from the literature), adults have been recorded in every month of the year, probably because they overwinter as adults.

The ecological information on E. serrifrons obtained from the literature is as follows: in Puglia (Monte Gargano), two specimens were collected in June, on the bracket fungus, Ganoderma lucidum, in a beech forest (Schawaller, 2002); in Spain (Extremadura), seven specimens were caught by a light trap, from May to July, in an old-growth chestnut woodland (Castro Tovar et al., 2008) and several specimens by window traps, from May to July, in a landscape dominated by Quercus pyrenaica and Q. rotundifolia, in the province of Salamanca (E. Micó, pers. com.); on Corsica, nine specimens were recorded in May, in a small and whitish bracket fungus, within a hollow trunk of an oak (Soldati et al., 2009). The specimens collected in southern Italy (Basilicata), and quoted in the present paper, were found in June, in a decaying bracket fungus (unidentified) on the bark of a dead black poplar (Populus nigra). The habitat was riparian woodland, with scattered trees of willows (Salix spp.) and Populus nigra. In Spain, the species was collected by window traps (H. Brustel, pers. com.) and also directly found in Inonotus sp. on Fraxinus (E. Micó, pers. com.). The Syrian records were for June, from a mixed forest consisting of both deciduous (Quercus) and coniferous trees (Abies); unfortunately, the collector does not record the ecological details of this capture. The seasonal range of $E$. serrifrons appears to be more limited (May to October) but this is probably due to the fewer records for this extremely rare species. Both species are active flyers as they were caught by both aerial window and light traps. 


\section{CONCLUSIONS}

In the light of the results, the geographic range of both species of the genus Eledonoprius is larger than expected but highly fragmented. E. armatus has a wide range throughout Europe, but most of the records are old and restricted to approximately 50 localities from central and southern Europe whereas E. serrifrons seems to be restricted to Mediterranean and Near Eastern countries.

The scattered occurrence of these beetles is probably because there are few old hollow trees due to human management. According to the literature, these species have narrow ecological niches (Brustel et al., 2004; Soldati et al., 2009) the most important feature of which is their dependence on hollow old deciduous trees (rarely coniferous trees) attacked by bracket fungi. Bracket fungi are the food resource of these beetles, even when found where sporocarps are temporarily lacking. Probably, these beetles survive by feeding on the rotten wood within large tree cavities, where bracket fungi mycelia occur and contribute to wood degradation.

Rarity and the scattered distribution of E. armatus within its geographic range is probably a consequence of its trophic specialization and the reduction in the area of mature deciduous forests that has occurred in Europe (Kompantseva \& Tschigel, 2000). In fact, this species is considered (Español, 1985) to be a relict species of the primeval European forests. More recently, $E$. armatus was included among the 54 beetle species "assigned to category 1 (Urwald relict species in the closest sense)", of those species considered to be associated with primeval forest ("Urwald") structures and features (Müller et al., 2005). Localities of $E$. armatus in southern Sweden are also in relict deciduous forests, as are some of the forests in the Caucasus and Crimea, which are considered to be refuges for these beetles (Kompantseva \& Tschigel, 2000). The Italian localities of these beetles at Allumiere and Monte Venere, which were studied during this research project, are both in relict stands of primeval beech forests that covered part of the Latium region during the cool and humid phases of the Pleistocene and are now isolated from the large beech forests that still widely occur along the Apenninic range (Magri, 1998, 2008). In contrast, the site at Bosco Polverino is in an abandoned cork oak stand recolonized by deciduous broadleaf trees. Therefore, in spite of their relict nature, the species of the genus Eledonoprius, originally associated with old-growth forests, can also survive in tree stands transformed by human activities provided old trees with bracket fungi, which are their main source of food, occur there.

ACKNOWLEDGEMENTS. This paper reports part of the results of the project "Census and monitoring of saproxylic fauna in protected areas of the Latium Region", financed by the Parks Regional Agency (ARP). We are grateful to the following colleagues who provided us with unpublished data, useful information and literature: V. Aliquò, Palermo, Italy; M. Baena, Departamento de Biología y Geología, I.E.S Trassierra, Córdoba, España; D. Baiocchi, Roma; A. Bernicchia, Dipartimento di Scienze e tecnologie agroalimentari, Università di Bologna; S. Fattorini, Roma; H. Brustel, Toulouse, France; E. Micó, Universidad de Alicante, Spain; W. Schawaller, Staatliches Museum für Naturkunde, Stuttgart, Germany and F. Soldati, Office National des Forêts, Laboratoire National d'Entomologie Forestière, Quillan, France. We are also grateful to the authorities of the "Agenzia Regionale dei Parchi-Lazio" who helped us with our research in many ways, in particular V. Consoli, G. Tallone, I. Sinibaldi and D. Capizzi. Father K. Milewski provided a translation of the Polish and E. Colonnelli the Russian literature. F. Bellotti, D. D'Amato, J. Liberti, A. Mazziotta, L. Redolfi De Zan, S. Rossi De Gasperis and G. Zirpoli helped us with the fieldwork.

\section{REFERENCES}

Bernichia A. 2005: Fungi Europaei. Polyporaceae. Edizioni Candusso, Alassio, $807 \mathrm{pp}$.

Brustel H., Valladares L. \& van Meer C. 2004: Contribution à la connaissance des Coléoptères saproxyliques remarquables des Pyrénées et des régions voisines. - Bull. Soc. Entomol. Fr. 109: 413-424.

Brustel H., Gouix N., Valladares L., Soldati F. 2008: Deux Tenebrionidae (Coleoptera) nouveaux pour les PyrénéesOrientales: Eledonoprius armatus (Panzer, 1799) et Phtora crenata (Germar, 1836). - R.A.R.E. / Rev. Assoc. Roussill. Entomol. 17: 33-35.

Castro Tovar A., Sáez Bolaño J. \& Baena M. 2008: Nuevas citas de Bolitophagini Kirby, 1837 (Coleoptera, Tenebrionidae) de España. Bol. SEA 42: 361-365.

Escalera M.M. DE La 1914: Los Coleópteros de Marruecos. Trab. Mus. Nac. Cien. Nat. 11: 1-553.

Español F. 1985: Les Bolitophaginae de la fauna española (Col. Tenebrionidae). - Publ. Dpto. Zool. Univ. Barcelona 11: $61-64$.

IABLOKov A. 1939: Note sur le Boletophagus armatus Panz. Rev. Fr. Entomol. 6: 26-28.

Kompantseva T.V. \& Tschigel D.S. 2000: New data on the distribution and biology of Eledonoprius armatus (Panzer, 1799) (Coleoptera: Tenebrionidae). — Russ. Entomol. J. 9: 139-141.

LundBerg S. \& EhNSTRÖM B. 2006: Faktablad: Eledonoprius armatus - taggig svartbagge. ArtDatabanken, SLU. http://www.artfakta.se/Artfaktablad/Eledonoprius_Armatus_10 0891.pdf

MAGRI D. 1998: Quaternary history of Fagus in the Italian peninsula. - Ann. Botan. 56: 147-154.

MAGRI D. 2008: Patterns of post-glacial spread and the extent of glacial refugia of European beech (Fagus sylvatica). - J. Biogeogr. 35: 450-463.

MateleshKo A. 2005: Coleoptera (Insecta) - micetobionts of fungi genus Pleurotus (Fr.) Kumm. of the Ukrainian Carpathians. - Sci. Bull. Uzhgorod Univ. (Ser. Biol.) 17: 127-130 [in Russian, English abstr.].

Müller J., Bussler H., Bense U., Brustel H., Flechtner G., Fowles A., Kahlen M., Möller G., Mühle H., Schmidl J. \& ZABRANSKY P. 2005: Urwald relict species - Saproxylic beetles indicating structural qualities and habitat tradition. - Waldökologie Online 2: 106-113.

Ponel P. 1993: Coléoptères du Massif des Maures et de la dépression permienne périphérique. - Faune de Provence 14: $5-23$.

ReitTer E. 1890: Neue Coleopteren aus Europa, den angrenzenden Ländern und Sibirien, mit Bemerkungen über bekannte Arten. Zehnter Teil. - Dt. Entomol. Z. 1890: 165-176.

Schawaller W. 2002: Evidence of two species of Eledona Latreille and Eledonoprius Reitter in Europe (Coleoptera, Tenebrionidae). — Entomol. Blätter 98(1): 111-114.

Soldati F. \& Coache A. 2004: Resultats d'une première campagne de prospection entomologique en Corse (Coleoptera, Tenebrionidae). - Bull. Soc. Linn. Bordeaux 32: 1-25.

Soldati F., Soldati L. \& Thieren Y. 2009: Découverte en Corse d'Eledonoprius serrifrons (Reitter, 1890), une espèce nouvelle pour la faune de France (Coleoptera, Tenebrionidae, Bolitophagini). - Bull. Rutilans 12(2): 33-36.

STeBnicKa Z. 1991: Klucze do oznaczania owadow Polski [Keys for the Identification of Polish Insects]. XIX, Coleoptera; 91, Tenebrionidae, Boridae. Polskie Towarzystwo Entomologiczne, Wroclaw, $93 \mathrm{pp}$.

TAMISIER J.P. 2005: Contribution à la connaissance des Tenebrionidae du Lot-et-Garonne (Coleoptera). - Bull. Soc. Linn. Bordeaux 33: 209-224.

Received November 10, 2011; revised and accepted August 20, 2012 